\title{
Is Being Plastic Fantastic? Mechanisms of Altered Plasticity after Developmental Traumatic Brain Injury
}

\author{
Christopher C. Giza ${ }^{a, b, c, d}$ Mayumi L. Prins ${ }^{b, c, d}$ \\ ${ }^{a}$ Division of Pediatric Neurology, Department of Pediatrics, ${ }^{b}$ Division of Neurosurgery, Department of Surgery, \\ 'UCLA Brain Injury Research Center, and d Brain Research Institute, David Geffen School of Medicine at UCLA, \\ Los Angeles, Calif., USA
}

\section{Key Words}

Experience-dependent plasticity · Head injury •

Neurotransmitter $\cdot$ Pediatric traumatic brain injury

\begin{abstract}
Traumatic brain injury (TBI) is predominantly a clinical problem of young persons, resulting in chronic cognitive and behavioral deficits. Specifically, the physiological response to a diffuse biomechanical injury in a maturing brain can clearly alter normal neuroplasticity. To properly evaluate and investigate developmental TBI requires an understanding of normal principles of cerebral maturation, as well as a consideration of experience-dependent changes. Changes in neuroplasticity may occur through many age-specific processes, and our understanding of these responses at a basic neuroscience level is only beginning. In this article, we will particularly discuss mechanisms of TBI-induced altered developmental plasticity such as altered neurotransmission, distinct molecular responses, cell death, perturbations in neuronal connectivity, experience-dependent 'good plasticity' enhancements and chronic 'bad plasticity' sequelae. From this summary, we can conclude that 'young is not always better' and that the developing brain manifests several crucial vulnerabilities to TBI.

Copyright ๑ 2006 S. Karger AG, Basel
\end{abstract}

\section{Introduction}

Traumatic injury to the developing brain is distinct from adult traumatic brain injury (TBI) in many ways. One major difference is that the developing brain is more malleable to external stimuli, or more plastic, a characteristic that has often been touted as a significant advantage with regard to recovery of function. However, children who suffer TBI are well known to develop chronic cognitive and behavioral disturbances [Ewing-Cobbs et al., 1997, 1998; Fay et al., 1994; Jaffe et al., 1993; Levin et al., 1982, 2002]. Children also have a higher incidence of posttraumatic epilepsy [Annegers et al., 1998; Annegers and Coan, 2000] than adults. Infants and toddlers might arguably have the most plasticity and yet actually seem to have some of the worst developmental outcomes after significant TBI [Barlow et al., 2005; Ewing-Cobbs et al., 1997; Levin, 2003; Levin et al., 1992; Taylor and Alden, 1997]. Clearly, plasticity is not simply an all-or-none beneficial response that just happens to be more robust in development, it is a complex series of molecular, cellular and physiological events that must be carefully orchestrated for optimal developmental outcome. While the effects of ischemia, seizures and other brain injuries have been extensively studied during development, TBI, the number

\section{KARGER}

Fax +4161306 1234

E-Mail karger@karger.ch

www.karger.com
(C) 2006 S. Karger AG, Base

0378-5866/06/0285-0364\$23.50/0

Accessible online at:

www.karger.com/dne
Christopher C. Giza, MD

Division of Neurosurgery, David Geffen School of Medicine at UCLA Room 18-235 NPI, Mail Code 703919

Los Angeles, CA 90095 (USA)

Tel. +1 310825 3550, Fax +1 310794 2147, E-Mail cgiza@mednet.ucla.edu 
one cause of pediatric death and disability, has not. Here, we will describe the basic principles of developmental plasticity and review the current literature with regard to potential mechanisms underlying altered plasticity following TBI in the immature brain. Better delineating the nature and timing of these processes will provide a foundation for the therapeutic manipulation of neuroplasticity to enhance functional recovery in the developing brain.

\section{Plasticity: Drastic or Fantastic?}

Plasticity is defined by Merriam-Webster as 'the capacity to vary in developmental pattern, phenotype or behavior according to varying environmental conditions'. In general, this ability has been viewed as an advantageous quality, one that permits the individual to change in response to external cues, and thus, make it better suited to survive and thrive in the current circumstances. However, to a large degree, the beneficial results of plasticity in the nervous system appear to be contingent upon the inciting stimuli. Physiological stimuli such as the presence of lightactivating visual pathways would seem to be necessary for promoting normal development of the relevant neural circuitry. On the other hand, pathological or abnormal stimuli (or the absence of normal stimuli), such as persistent dark rearing, can result in aberrant neuroplasticity with subsequent abnormal developmental outcomes. These 'abnormal' outcomes may not be distinctly deleterious and, in fact, may confer some advantages to the individual/pathway/neuron in the 'abnormal' environment. However, upon exposure back into a normal environment, these changes are likely to be suboptimal.

Other examples of the 'drastic versus fantastic' nature of developmental plasticity are of tremendous potential clinical relevance. One type of beneficial plasticity is the response of the brain to enriching environmental conditions. In both animals and humans, stimulating environments trigger outgrowth of neural projections, resulting in increased dendritic arborization and cognitive enhancement [Greenough et al., 1973; Jacobs et al., 1993; Rosenzweig and Bennett, 1996]. The ability of the brain to benefit from environmental stimulation appears most robust during brain maturation. On the other hand, excessive stimulation of particular pathways, as may occur during seizures or other types of brain injury, can also promote outgrowth of abnormal neural connections, as well as development of circuitry that subsequently leads to epilepsy, and interferes with normal cognitive development.

Plasticity after Developmental Traumatic Brain Injury

\section{Principles of Plasticity and Development after Injury}

Type of Injury

Much of our current understanding about developmental plasticity and recovery from injury comes from studies of focal brain lesions induced at particular developmental stages. Focal sensorimotor cortex lesions sustained in development show better recovery than similar lesions in adulthood. This 'younger is better' paradigm was originally described in primates by Margaret Kennard [1942] and has been dubbed the 'Kennard Principle.' This phenomenon has been ascribed to the enhanced plasticity and ability for reorganization present in the developing brain, particularly in the setting of a unilateral focal injury. Following surgical hemidecortication, anatomical recovery (brain weight, cortical thickness, brain region cross-sectional area) and behavioral outcome (Morris water maze, foot faults, beam walking, claw cutting) were best in neonatally lesioned rats, while rats lesioned as adults had the largest deficits [Kolb and Tomie, 1988]. Similar results were seen when kittens or adult cats underwent hemispherectomy - kittens performed close to controls, while adult-lesioned cats showed abnormal limb preference and reduced locomotion [Burgess and Villablanca, 1986].

Lesion location is also important in determining developmental vulnerability or resistance to functional impairment. Frontal lobectomy or lesions of the dorsolateral frontal cortex in monkeys resulted in less impairment on delayed response testing when the lesions were induced in infancy rather than as juveniles [Goldman, 1971]. In fact, monkeys that underwent dorsolateral frontal lesions in infancy performed similarly to nonlesioned controls at 1 year of age. However, when tested for visual pattern discrimination, monkeys with dorsolateral frontal cortex lesions from infancy actually showed worse 1-year outcomes than those lesioned as juveniles. On the other hand, orbitofrontal lesions showed no such sparing with age for multiple cognitive tasks (delayed response, visual pattern discrimination, delayed alternation, object reversal) [Goldman, 1971; Miller et al., 1973].

Circumstances become more complicated if bilateral homotypic cortical areas are lesioned. Following bilateral motor cortex lesions, postnatal day 10 (P10)-lesioned rats showed better behavioral performance (Whishaw reaching task, beam walking) than adult or P1-lesioned animals, although anatomical measures (brain weight, cortical thickness) seemed to favor the adult-lesioned animals [Kolb et al., 2000]. Bilateral medial frontal lesions showed that the youngest rats (P3, P6) actually had worse ana-

Dev Neurosci 2006;28:364-379 


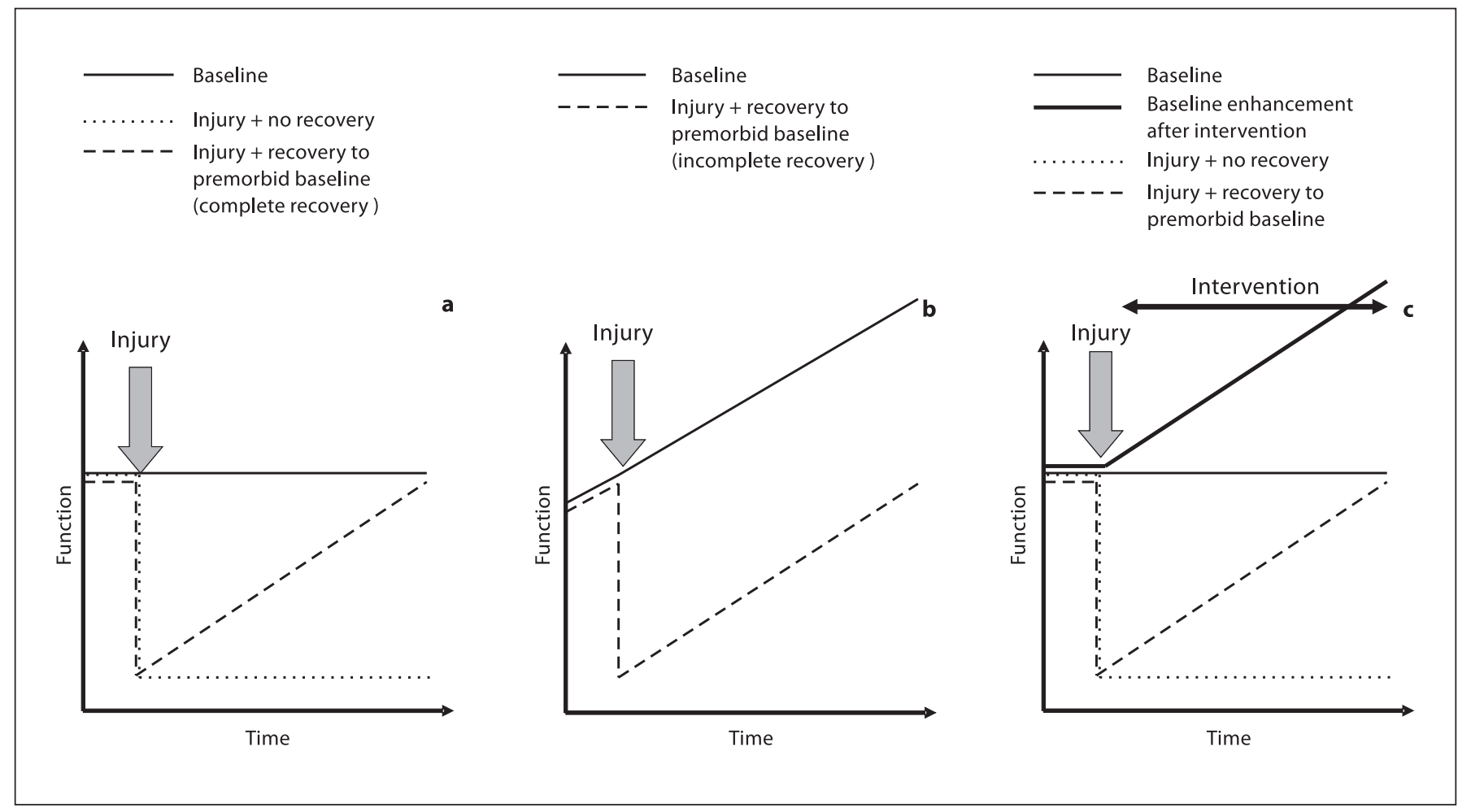

Fig. 1. Recovery of function after injury in different theoretical models. a Static (mature) model: baseline function does not change with time (solid line). Injury with no recovery shows downward step in function (dotted line). Injury with gradual return to premorbid baseline results in complete recovery (dashed line). b Dynamic (developmental) model: baseline function improves with time (solid line). Injury with gradual return to premorbid baseline results in incomplete recovery (dashed line). c Dynamic (interventional) model: baseline function shows no change with time (thin solid line), but following intervention, baseline function improves with time (thick solid line). Injury (followed by intervention) with return to premorbid baseline represents incomplete recovery (dashed line).

tomical and functional outcomes [Kolb et al., 1996]. Furthermore, bilateral medial frontal lesions in the perinatal period (P2) resulted in markedly reduced brain weight, dendritic arborization and spine density, leading to the conclusion that, in some settings, 'earlier may be worse' [Kolb and Cioe, 2000].

Of course, generally, TBI is a diffuse biomechanical injury that may have focal or multifocal components superimposed. Thus, while we can learn much from these ageat-lesion studies, it is essential to specifically model and study TBI in the developing brain [Prins and Hovda, 2003].

\section{Recovery to Baseline}

One important aspect of measuring physiological responses and functional outcomes during development is the fact that both physiology and function are often dy- namically changing over time. This principle must be considered for both clinical management and research investigations involving the care and study of immature or pediatric populations. For example, in a more static (adult) model, a given function remains constant over time, as illustrated in figure 1a. If an injury occurs, there may be a permanent deficit (fig. 1a, dotted line) or an acute reduction in function that slowly recovers over time. At some point, if and when the level of function returns to the premorbid level, recovery is said to be complete (fig. 1a, dashed line). However, this paradigm does not hold in a dynamic (developing) model. In a developing model, the level of function in normal subjects is changing over time. After developmental injury, while functional recovery may return to the premorbid baseline (fig. $1 \mathrm{~b}$, dashed line), the baseline function of normal peers has already moved on (fig. 1b, solid line). Therefore, the duration of 
recovery, the rate of functional change across development and the presence/timing of critical windows all become important measures to determine whether the injured immature brain can actually fully recover to an agematched baseline after injury. In the setting of pediatric brain injury, functional comparisons between injured and control subjects must be made at similar developmental ages.

It is also possible that the immature brain may appear to have a complete functional recovery, but that the strength of this recovery is limited. One example of this is a study of unilateral excitotoxic injury in P7 rats. Early after injury, motor deficits are seen contralateral to the damage, but recovery occurs by $3-4$ weeks. However, administration of an N-methyl-D-aspartate (NMDA) receptor antagonist after the time of full recovery is able to transiently reinstate the deficit [Felt et al., 2002].

One final related concept to be introduced is that of 'growing into the lesion'. This idea purports that if a particular function is not normally well developed at the time of injury, then such a deficit may not necessarily be observed until a later developmental stage. In the study of dorsolateral versus orbital frontal lesions in monkeys described above [Goldman, 1971], the dorsolateral frontal lesioned animals, which appeared to show developmental sparing when tested 1 year after the lesion, actually demonstrated relative impairments on the delayed alternation task when tested after 2 years. This illustrates that developmental outcome should be interpreted not only based on age at injury, but also on age at testing.

\section{Effects of Experience}

An additional critical consideration when managing or investigating recovery from developmental brain injury is the presence of salient environmental stimuli. In a mature brain, functional enhancements may occur in response to appropriate environmental conditions, such as exploring an enriched environment or taking lessons in a foreign language. In these situations, the normally flat time course of function is now changed to a developmental one, with a change in function marked over time in the presence of the prescribed intervention (fig. 1c, thick solid line). The effects of injury on this now dynamic system may be mediated by a direct injury-induced deficit or by an injuryinduced impaired responsiveness to the intervention. Thus, in situations where there is an environmentally induced increase in function, the appropriate comparison is not simply with uninjured controls, but also with uninjured controls exposed to the same environment or therapy (fig. 1c). In this case, as described in the preceding

Plasticity after Developmental Traumatic Brain Injury discussion, recovery to premorbid baseline is an inadequate goal, as uninjured subjects experiencing the beneficial intervention will have gained enhanced functions over the same time period. In other words, when studying the recovery from pediatric TBI, one must control not only for age, but also for environmental conditions that can influence developmental trajectory (i.e. maternal behavioral factors, living conditions, social interactions).

Finally, it is important to realize that brain maturation occurs in situations where environmental conditions and training are superimposed upon normal developmental changes. One must carefully consider these complexities in the investigation and interpretation of injury recovery responses. Both normal maturational changes and response to environmental stimuli will affect functional outcomes measured during recovery from pediatric TBI.

\section{Mechanisms of Altered Plasticity}

The multiple variables operant during the recovery from developmental TBI are probably more easily addressed in basic science studies using well-characterized injury models and strict age- and environment-matched developmental controls than in clinical pediatric TBI studies, where the ability to control these variables is quite limited. Once an injury response or recovery mechanism is characterized in the preclinical setting, it would be possible to design well-controlled clinical studies to ensure that these findings are translatable back to pediatric braininjured patients. In the following section, we will review the current status of basic science investigations into mechanisms of neuroplasticity following developmental TBI.

\section{Changes in Neurotransmission}

A major potential mechanism of alterations in developmental neuroplasticity following TBI involves changes in neurotransmission (table 1). Clinically, dysfunctional neurotransmission has been implicated in many sequelae of pediatric TBI, including memory impairment and attention problems [Blitzer and Lombroso, 2003; Griffin et al., 2003; Johnston, 2004; Konrad et al., 2003]. In both immature and adult TBI models, abnormalities have been reported in multiple neurotransmitter systems, including glutamatergic [Biegon et al., 2004; Giza et al., 2006; Kumar et al., 2002; Miller et al., 1990; Osteen et al., 2004; Sihver et al., 2001], $\gamma$-amino-butyric acid (GABA)ergic [Lowenstein et al., 1992; Sihver et al., 2001], cholinergic [Dixon et al., 1996, 1997, 1999; Gorman et al., 1996; Shao et al., 
Table 1. Neurotransmitter changes

\begin{tabular}{|c|c|c|c|}
\hline Neurotransmitter & System component & $\begin{array}{l}\text { Change after } \\
\text { developmental TBI }\end{array}$ & Change after adult TBI \\
\hline Glutamate & $\begin{array}{l}\text { NMDA receptor binding } \\
\text { NMDA receptor expression } \\
\text { NMDA-mediated calcium flux } \\
\text { NMDA receptor electrophysiology } \\
\text { glutamate antagonist effect on neuron survival } \\
\text { other glutamate receptor-related genes } \\
\text { (GluR4, GluR5, KA1, GRIP) }\end{array}$ & $\begin{array}{l}\downarrow_{\mathrm{H}} 2 \text { days, } 4 \text { days } \\
\downarrow \text { C } 1 \text { day } \\
\downarrow_{\mathrm{H}} \text { LTPi } 1 \text { day, } 2 \text { days }^{5} \\
\downarrow_{\mathrm{H}} \\
\downarrow_{\mathrm{C}^{8}} \\
\downarrow_{\mathrm{H}}<1 \text { day }^{16}\end{array}$ & 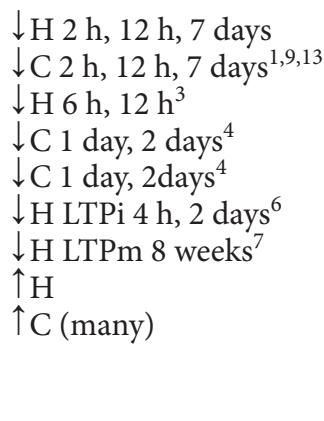 \\
\hline GABA & \multicolumn{2}{|l|}{ GABA receptor binding } & $\begin{array}{l}\downarrow_{\mathrm{H}} 2 \mathrm{~h} \\
\downarrow_{\mathrm{C} 2 \mathrm{~h}, 12 \mathrm{~h}^{9}}\end{array}$ \\
\hline Dopamine & $\begin{array}{l}\text { aromatic amino acid decarboxylase activity } \\
\text { catechol-O-methyltransferase and } D_{1} \text { receptor genes }\end{array}$ & $\begin{array}{l}\uparrow \mathrm{C} 2 \text { days }^{15} \\
\uparrow \mathrm{C}<1 \text { day }^{16}\end{array}$ & \\
\hline $\begin{array}{l}\mathrm{H}=\text { Hippocam } \\
\text { muscarinic acetylc } \\
{ }^{1} \text { Miller et al., } 1 \\
\text { et al., 2000. }{ }^{8} \text { Pohl } \\
{ }^{14} \text { Phillips et al., } 19\end{array}$ & $\begin{array}{l}\text { is; C = cortex; LTPi }=\text { long-term potentiation inductic } \\
\text { line; FC = frontal cortex; PC = parietal cortex. } \\
0 .{ }^{2} \text { Giza et al., 2006. }{ }^{3} \text { Kumar et al., } 2002 .{ }^{4} \text { Osteen et al. } \\
\text { al., 1999. }{ }^{9} \text { Sihver et al., } 2001 .{ }^{10} \text { Shao et al., } 1999 .{ }^{11} \text { Go } \\
{ }^{15} \text { Walter et al., 2005. }{ }^{16} \text { Prins and Giza, } 2006 .\end{array}$ & $\begin{array}{l}\Gamma \mathrm{Pm}=\text { long-term poten } \\
\text { 4. }{ }^{5} \text { D'Ambrosio et al., } 19 \\
\text { et al., } 1996 .{ }^{12} \text { Prins et }\end{array}$ & $\begin{array}{l}\text { maintenance; } \mathrm{mACh}= \\
\text { ick et al., } 1998 .{ }^{7} \text { Sanders } \\
\text { 3. }{ }^{13} \text { Biegon et al., } 2004 .\end{array}$ \\
\hline
\end{tabular}

1999; Sihver et al., 2001] and aminergic [Walter et al., 2004] neurotransmission.

Indiscriminate activation of glutamate receptors is a fundamental component of biomechanical neural injury [Faden et al., 1989; Katayama et al., 1990; Kawamata et al., 1992]. This initial flood of glutamate is followed by an apparent downregulation of NMDA receptors [Biegon et al., 2004; Giza et al., 2006; Kumar et al., 2002; Miller et al., 1990; Osteen et al., 2004; Sihver et al., 2001]. The time frame of these reductions ranges from a few hours to several days after injury depending upon injury model, age at injury and methodology used to measure receptors (mRNA, protein, receptor binding).

In uninjured immature animals, the NR2A subunit of the NMDA receptor shows dynamic developmental regulation, increasing dramatically in many brain regions during maturation - somatosensory cortex [Flint et al., 1997], visual cortex [Roberts and Ramoa, 1999], cerebellum [Takahashi et al., 1996] and hippocampus [Tovar and Westbrook, 1999] - and also increasing in response to specific environmental conditions, i.e. nurturing maternal behaviors [Liu et al., 2000], switching from dark to light rearing [Quinlan et al., 1999a, 1999b] and enriched environment housing [Tang et al., 2001]. It appears that upregulation of NR2A is a fundamental molecular process that underlies maturation of these excitatory circuits. Interestingly, fluid percussion injury causes a reduction in cortical NR2A in the first 1-2 days after injury in adults [Osteen et al., 2004] and P19 pups [Giza et al., 2006; Santa Maria et al., 2005]. Furthermore, pups also show a longer-lasting age-specific reduction in the NR2A subunit in the hippocampus until postinjury day 4 [Giza et al., 2006; Santa Maria et al., 2005]. Electrophysiological studies demonstrate impaired induction of long-term potentia- 
tion (LTP) with preserved long-term depression in the developing hippocampus after TBI [D'Ambrosio et al., 1998]. Impairment of LTP induction without affecting longterm depression has been shown to result from NR2Aspecific inhibition of the NMDA receptor [Liu et al., 2004]. This raises the intriguing idea that impaired glutamatergic neurotransmission underlies deficits in cognition and plasticity after TBI and that perhaps the developing brain is uniquely vulnerable to the consequences of diminished excitatory activity.

GABAergic neurotransmission impairments, reduced inhibition and hyperexcitability have clearly been demonstrated after TBI in adults, particularly in hippocampal circuitry [Golarai et al., 2001; Toth et al., 1997]. Post-TBI reductions in GABA receptor binding have also been reported in mature animals [Sihver et al., 2001]. Reduction or genetic blockade of GABAergic activity impairs plasticity during critical periods of brain maturation [Hensch et al., 1998]. In the immature brain, there is evidence of hippocampal hyperexcitability early after fluid percussion injury [D’Ambrosio et al., 1999]. However, the specific contribution of GABAergic dysfunction to this hyperexcitability should be interpreted cautiously, as other mechanisms (such as glial dysfunction) have also been implicated.

Cholinergic pathways are clearly important for cognition and normal development [Berger-Sweeney, 2003; Ricceri, 2003]. An impairment of this neurotransmitter system has been reported in adult models of TBI, including early reductions in choline acetyltransferase, the biosynthetic enzyme for acetylcholine [Gorman et al., 1996]. Following adult TBI, decreased muscarinic acetylcholine receptor binding and protein levels are seen [Shao et al., 1999; Sihver et al., 2001], and evoked release of acetylcholine is diminished [Dixon et al., 1997]. Perhaps in response to this injury-induced cholinergic dysfunction, vesicular acetylcholine transporter levels actually increase chronically after adult TBI [Dixon et al., 1997; Shao et al., 1999].

While there have been no direct measures of post-TBI cholinergic neurotransmission in the immature animal, one study examined alterations in the regrowth of cholinergic projections following developmental TBI and found evidence of impaired neuroplasticity in the hippocampal dentate gyrus [Prins et al., 2003]. Despite ample evidence of altered cholinergic neurotransmission after TBI in mature animals [Dixon et al., 1999; Shao et al., 1999] and clear developmentally mediated changes in cholinergic receptors [Adams et al., 2002; Miyoshi et al., 1987], further work is necessary to more precisely determine how this neurotransmitter system is involved in plasticity following TBI to the immature brain.

Chronic alteration in dopaminergic systems has been implicated in some of the cognitive and attention problems seen in patients after pediatric TBI. Recently, Walter et al. [2004] used positron emission tomography to estimate the activity of aromatic amino acid decarboxylase (the final enzyme in dopamine biosynthesis) after fluid percussion injury in newborn and juvenile piglets. In this study, severe TBI triggered a significant upregulation of amino acid decarboxylase, but only in neonates and not in the juvenile piglets [Walter et al., 2004]. This is the first experimental evidence of TBI-induced age-specific effects on dopaminergic neurotransmission. The behavioral and developmental consequences of these changes remain to be seen.

\section{Molecular Alterations: Gene and Protein Expression}

Complex pathophysiological events, such as the response to TBI and the normal path of cerebral maturation, are particularly amenable to investigations using molecular screening techniques to delineate major pathways involved in these multifaceted processes. Using standard microarray techniques, we investigated the postinjury gene expression profile in the preweanling male rat brain (P19). Specifically, pups were killed, fresh brains were harvested and brain regions dissected immediately on ice within $24 \mathrm{~h}$ of both mild and severe lateral fluid percussion injury (FPI) and compared with sham animals ( $\mathrm{n}=$ 4 per group). FPI was directed via a 3 -mm-diameter craniotomy located $3 \mathrm{~mm}$ posterior and $6 \mathrm{~mm}$ lateral to the bregma, as described previously [Giza et al., 2002; Prins et al., 1996]. Mild injury was defined as loss of toe pinch response $<45 \mathrm{~s}$ and severe injury as loss of toe pinch $>120$ s. This loss of toe pinch represents a simple postinjury physiological measure which correlates with atmospheric pressure, duration of apnea and expression of c-fos expression in our prior work [Giza et al., 2002]. In no case was the dura breached, and similarly injured animals at this age do not go on to develop a histological lesion [Gurkoff et al., 2006]. RNA was isolated from the ipsilateral cortex and hippocampus using guanidine thiocyanate extraction [Chomczynski and Sacchi, 1987]. Affymetrix rat gene RG U43A arrays were used. Analysis of expression data was performed using Genesifter software (www.Genesifter.net), setting the significance at changes greater than 2.0 fold up- or downregulated compared with sham. This analysis was chosen to minimize the amount of false positives, while realizing that differentially expressed genes with higher individual variability or a lower 
Fig. 2. Gene expression changes by functional category after mild and severe developmental brain injury. a Proportion of gene changes ascribed to specific functional categories following mild injury. The greatest proportion of downregulated genes can be classified as genes related to neurotransmission/plasticity or growth factors/hormones. b Proportion of gene changes ascribed to specific functional categories following severe injury. Again, genes associated with neurotransmission/plasticity and growth factors/hormones represent a much larger percentage of downregulated than upregulated genes. ROS $=$ Reactive oxygen species.

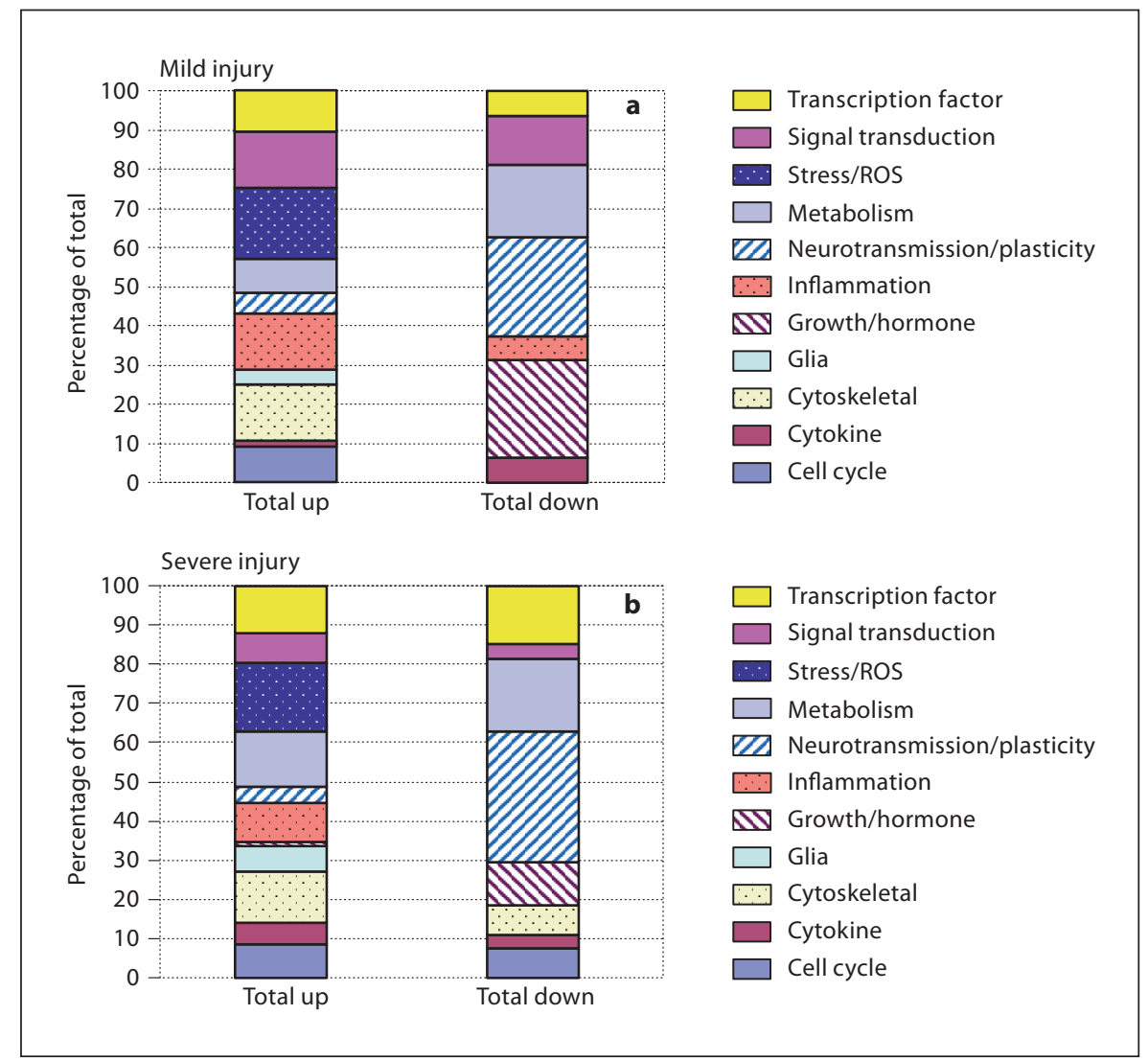

magnitude of change might not be detected as significantly different.

For mild injury, 60 genes were differentially expressed in injured versus sham animals. Forty genes were altered in the cortex (30 up and 10 down) and 32 were significantly changed in the hippocampus (26 up and 6 down). Following severe injury, 96 genes showed significant differences from sham. In the cortex, 58 genes were changed (48 up and 10 down), while in the hippocampus, 60 genes demonstrated differences (44 up and 16 down).

Categorizing the differentially expressed genes by primary function after mild or severe injury demonstrates global patterns of response that allow some general interpretations to be made. As might be expected, genes associated with stress/reactive oxygen species, inflammation or cytoskeletal proteins comprised a larger proportion of the significant changes marked by upregulation (fig. 2). Conversely, among all downward gene expression changes, a larger proportion was made up of genes related to neurotransmission/plasticity and growth factors/hormones. These patterns remained consistent between mild and severe injuries.
Of the genes designated as neurotransmitter/ion channel/plasticity genes, $4 / 7$ were downregulated by mild injury and $9 / 13$ by severe injury. Genes coding for growth factors/hormones were also predominantly reduced, $3 / 3$ by mild and $3 / 4$ by severe injury (table 2 ).

Regionally, the overall numbers of genes up- or downregulated were similar in both cortex and hippocampus, although there were some interesting differences based on gene function. Genes involving cell cycle, metabolism and reactive oxygen species were more often altered in the cortex, usually being upregulated. The gene categories showing injury effects preferentially in the hippocampus included cytoskeletal, inflammation and neurotransmission/plasticity. Most cytoskeletal and inflammation genes were increased, but those involving neurotransmission/ plasticity were generally reduced.

Impairment of glutamatergic systems has long been implicated in deficits of learning and memory. Interestingly, several genes coding for proteins associated with glutamate receptors and signaling were downregulated, including GluR4, GluR5, KA1 and GRIP (glutamate receptor interacting protein) (table 2). Following mild in- 
Table 2. Gene expression changes after mild and severe developmental TBI

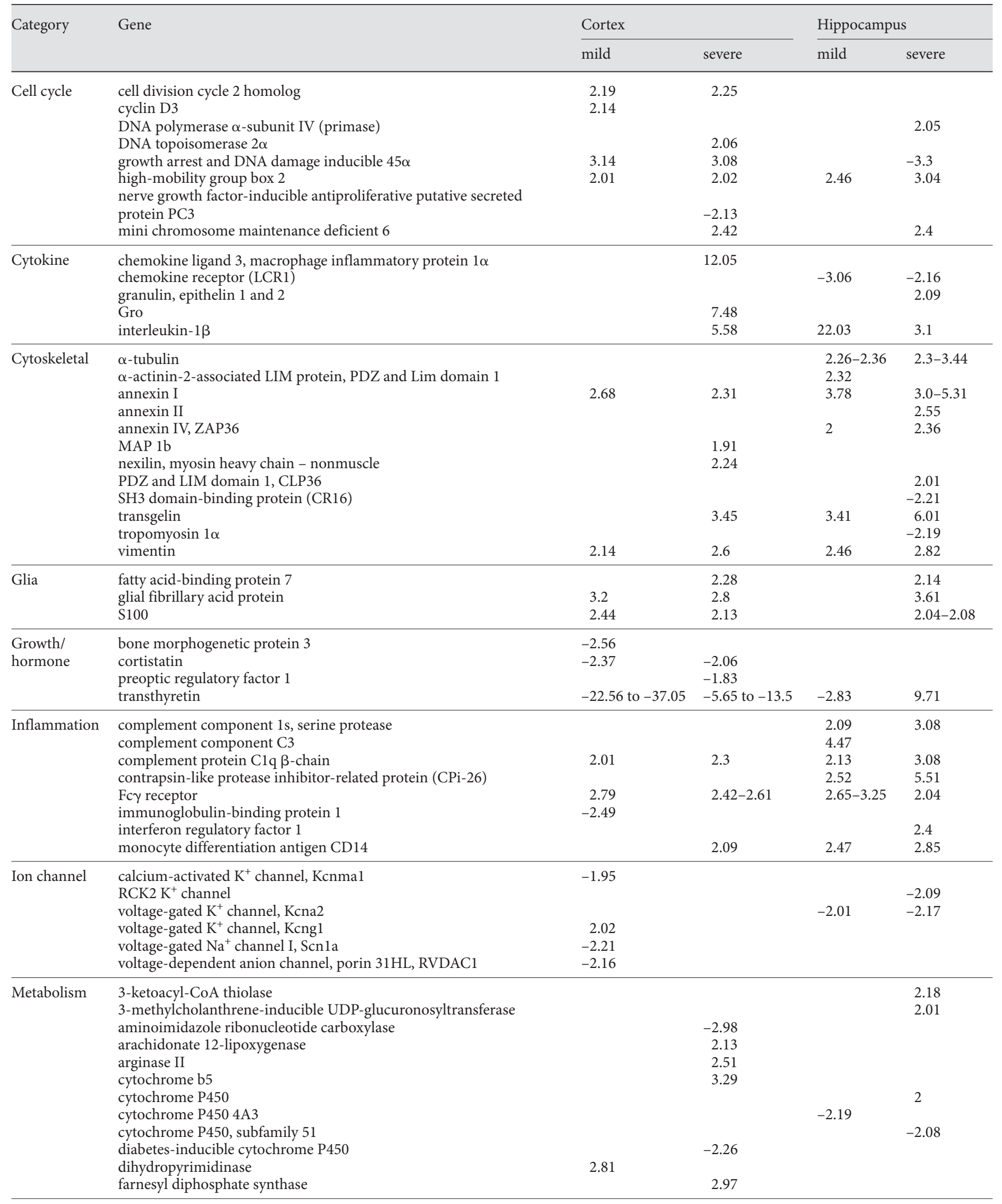


Table 2 (continued)

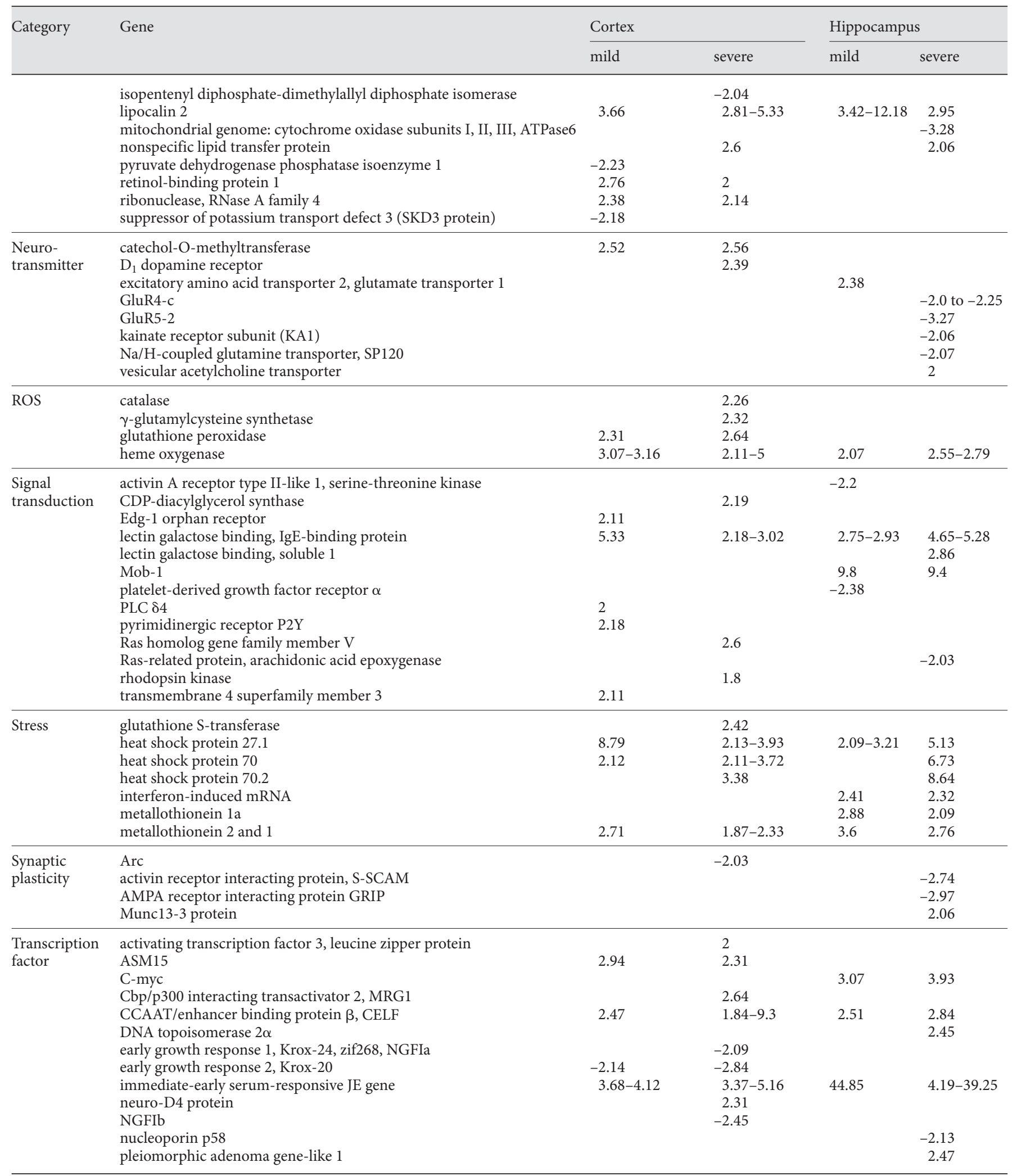


jury, the glutamate transporter EAAT2 (excitatory amino acid transporter 2) was upregulated (table 2). Upregulation of the glutamate transporter and downregulation of glutamate receptor subunits may both serve as means of functionally downregulating the glutamatergic system following the indiscriminate excitatory amino acid release triggered by biomechanical injury. The glutamatergic activity-dependent gene Arc also showed significant cortical downregulation following severe injury.

Among other neurotransmitter systems, the cholinergic marker VAChT (vesicular acetylcholine transporter) shows an upregulation in the hippocampus following severe injury, consistent with results seen in adults described above [Dixon et al., 1999; Shao et al., 1999]. Dopaminergic-related genes (catechol-O-methyltransferase and the $\mathrm{D}_{1}$ dopamine receptor) also showed upregulation after severe injury, albeit only in the cortex (table 2). Upregulation of dopamine biosynthetic enzyme activity has also been reported after fluid percussion injury in neonatal pigs [Walter et al., 2004], as mentioned earlier.

Gene expression profiling can provide a broad picture of a complex response, but ultimately, proteins are the effectors of this response at the cellular level. Thus, proteomic approaches are also valuable in breaking down the response to injury, particularly in the developing brain. The advantages of a proteomic approach are that it will identify changes that occur independent of transcriptional alterations, including increased/decreased protein degradation and, most importantly, posttranslational modification. For these reasons, gene array and proteomic results do not necessarily match; nonetheless, these two approaches can be strongly complementary. A proteomic approach was utilized in the preweanling rat (P17) looking at proteins from the dorsal hippocampus $24 \mathrm{~h}$ after controlled cortical impact (CCI) injury. Significant changes relevant to postinjury plasticity were detected and included reductions in several proteins associated with the cytoskeleton (actin $\beta$-chain $-37 \%$, tubulin $\alpha_{1} \alpha_{2}$-chain $-45 \%$, tubulin $\beta$-chain $-53 \%$ ), protein processing (glucose regulated protein $78-51 \%$ ) and signal transduction (phosphatidylinositol transfer protein $\alpha$ isoform $-27 \%$ ). Increases in free radical/cell stress proteins were also detected, including a $62 \%$ upregulation of superoxide dismutase [Jenkins et al., 2002].

In addition to these broad gene and protein profiling approaches, several investigators have targeted studies of specific plasticity-related genes following developmental TBI. Using a subset of genes specifically induced by depolarization (but not by trophic factors), Giza et al. [2002] reported age- and severity-specific transcriptional chang-

Plasticity after Developmental Traumatic Brain Injury es in the hippocampus. Nerve growth factor-induced protein $\mathrm{B}$, a transcription factor, is upregulated in a severitydependent fashion in the immature brain, but is increased independent of severity in adults. Synaptotagmin IV, a presynaptic calcium-binding protein that in distinction to other members of the synaptotagmin family inhibits synaptic activity, is increased only in developing animals after severe injury and not at all in adults [Giza et al., 2002].

Brain-derived neurotrophic factor (BDNF) is an activity-dependent molecule closely associated with experience-dependent plasticity which undergoes distinct developmental regulation. After mild lateral FPI in P19 rats, relative reductions in BDNF mRNA were noted between the ipsilateral and contralateral cortex and hippocampus, and protein levels of BDNF were significantly reduced $(-10 \%)$ in the ipsilateral occipital cortex at postinjury day 7 [Griesbach et al., 2002]. Studies in adults have shown that exercise-induced upregulation of BDNF and subsequent cognitive enhancement is impaired early after injury [Griesbach et al., 2004], suggesting that this reduction may also have relevance to plasticity and cognition in the developing animals. Most importantly, the immature animals demonstrated a pattern of impressive contralateral BDNF upregulation in both cortex and hippocampus up to 2 weeks after injury, perhaps revealing a distinct compensatory mechanism for plasticity in the developing brain [Griesbach et al., 2002].

Molecular markers of cellular stress and injury have also been examined following developmental TBI. While these changes may be more relevant to neuronal survival and cell death (see next section), cells that are sublethally damaged may survive in a dysfunctional state. With either cell loss or localized cellular dysfunction (or both), the remaining neuronal circuits may thus be altered and potentially interfere with normal cerebral maturation. Glutathione peroxidase, a critical enzyme involved in superoxide metabolism, is upregulated in the adult mouse cortex and hippocampus following CCI. However, in the P21 mouse, this increase is not seen, indicating a potential age-specific vulnerability to oxidative stress in the immature brain [Fan et al., 2003]. Other cellular stress molecules implicated in an age-specific pathophysiological response to developmental TBI include isoforms of heme oxygenase, which show a $>2$-fold induction in the P19 cortex and hippocampus following both mild and severe lateral FPI (table 2). The developmental implications of heme regulation after TBI have been recently reviewed [Chang et al., 2005]. Metallothionein I/II are also important molecules in the response to oxidative stress and show developmental regulation with lower basal levels in 
the immature brain. However, deafferentation injury (occipital cortex ablation) induces a far higher and earlier induction of metallothionein I/II in the lateral geniculate in 10-day-old mice compared with adults [Natale et al., 2004]. Metallothionein I/II gene expression is also significantly upregulated in the cortex and hippocampus of P19 rats following TBI, as described above (table 2).

\section{Cell Death: Necrosis and Apoptosis}

Histological damage and neuronal loss are not direct measures of plasticity, but can certainly have effects upon developmental plasticity by disconnecting circuits, causing local calcium accumulation in dying cells, triggering inflammation, altering the extracellular milieu and reducing trophic support. Postinjury cell death is distinctly different in the immature rat brain, which is particularly sensitive to excitotoxicity in the neonatal period (1st postnatal week) [Ikonomidou et al., 1989, 1996], but seemingly less so in the 2nd to 3 rd postnatal weeks, when compared with the adult brain. In fact, both weight drop and lateral FPIs seem to result in little neuronal loss in the preweanling (P15-19) rat [Adelson et al., 2001; Bittigau et al., 1999; Gurkoff et al., 2006; Prins et al., 1996]. This absence of overt cell death suggests that the molecular and physiological perturbations seen following developmental TBI are due in greater part to neuronal dysfunction rather than destruction. Tissue destruction is also dependent upon injury type, as CCI injury delivered to P21 mice [Tong et al., 2002] or P17 rats [Card et al., 2005] clearly does induce histological cell death.

However, in the neonatal period, the injury response is distinct. There is a peak in vulnerability to an excitotoxic lesion at P6-7 (hypobaric/ischemic injury or direct NMDA injection) [Ikonomidou et al., 1989]. This susceptibility to NMDA-mediated excitotoxicity is also seen after a weight drop/contusion TBI is administered to P7 rats. In this model, NMDA antagonists (but not $\alpha$-amino-3-hydroxy5-methylisoxazole-4-propionate antagonists) provide neuroprotection from necrotic neuronal death [Ikonomidou et al., 1996]. However, treatment with NMDA antagonists also appears to trigger a substantial wave of delayed apoptotic cell death in widespread brain regions $24-48 \mathrm{~h}$ after treatment [Bittigau et al., 1999; Pohl et al., 1999]. Furthermore, this delayed apoptotic effect has been seen in the absence of injury after other neonatal treatments that impair neural activity, including common anticonvulsants and general anesthetics [Bittigau et al., 2002; JevtovicTodorovic et al., 2003]. There is some evidence that this drug-induced enhancement of developmental apoptosis has long-term effects on plasticity, as cognitive impair- ments in spatial learning have been reported in neonatally treated rats, with anesthetics [Jevtovic-Todorovic et al., 2003] or MK801 [Adelson et al., 2002].

In addition to acute and subacute injury-induced cell death, there may also be a chronic evolving lesion after TBI. This has been well described in the adult brain after different models of injury, and ongoing neurodegeneration may occur as long as 1 year after the insult [Conti et al., 1998; Fox et al., 1998]. In this issue, using a developmental TBI model (P21 CCI in mice), Pullela et al. [2006] describe cortical lesion expansion and progressive hippocampal neuron loss as late as 4.5 months after the original injury.

\section{Perturbation of Neural Connectivity and Function}

Changes in neuronal circuitry are a critical part of normal development, and perturbations of this connectivity have been implicated in pediatric TBI-induced learning disabilities and psychiatric disorders [Kumar and Cook, 2002; Levin, 2003]. Lateral FPI in immature animals has been shown to result in alterations in anatomical connections that are not associated with functional improvement. Ip et al. [2002] reported increased dendritic branching in the parietal cortex of sham animals housed in enriched environment (EE), and these animals have been shown to be cognitively superior in spatial learning tasks [Fineman et al., 2000; Giza et al., 2005]. While injured animals reared in EE showed no dendritic expansion, injured animals maintained in standard housing conditions did show significant injury-induced dendritic expansion [Ip et al., 2002]; however, in this case, subsequent studies revealed that these injury-induced anatomical increases did not manifest as any functional advantage on cognitive tests [Fineman et al., 2000; Giza et al., 2005].

Using a clever system of pseudorabies virus (PRV) injection into the entorhinal cortex and retrograde transsynaptic transport, it has been possible to begin looking at functional connectivity after developmental TBI [Card et al., 2005]. The strength and pattern of the PRV immunohistochemical signal differed according to the number of synapses crossed, allowing for qualitative assessment of patterns of neural connections. Twenty-eight days after CCI on P17, the overall distribution of the PRV signal did not change, suggesting that the primary pathways remained intact. However, a significant increase in the magnitude of the PRV signal was detected in the neocortex and overall, leading the authors to conclude that this methodology would prove useful in further experiments to compare and contrast neural network development in the immature brain following injury. 
Electrophysiological studies have also demonstrated impairment of neural function after TBI. Twenty-four to $48 \mathrm{~h}$ following lateral FPI in P24-31 rat pups, the threshold for generation of a CA1 population spike was increased and no induction of LTP was possible [D'Ambrosio et al., 1998]. These results clearly show impaired responsiveness of this excitatory circuit after developmental TBI. Abnormalities in the generation and maintenance of LTP have also been reported following lateral FPI in adult animals [Sanders et al., 2000; Sick et al., 1998].

\section{Experience-Dependent Enhancement: Good Plasticity?}

Normal cerebral maturation in animals and humans can be substantially modified by an individual's environment. In fact, the effects of EE during development have been well characterized as a form of 'good plasticity' that results in lasting anatomical - rats [Greenough et al., 1973; Rosenzweig and Bennett, 1996] or humans [Jacobs et al., 1993] - and behavioral enhancements [Leggio et al., 2005; Noble et al., 2005; Venable et al., 1988].

Using the lateral fluid percussion model of TBI in P17-20 rat pups, Fineman et al. [2000] reported that injured pups showed no overt histopathology or impairment in spatial learning 1 month after the injury, when housed in standard conditions. However, they discovered that injured pups reared in an enriched environment for 17 days failed to develop the increases in cortical thickness and improved spatial learning capabilities seen in their uninjured controls [Fineman et al., 2000]. Thus, while there was no clear cortical atrophy, there was a failure of experience-dependent plasticity. Enriched environment rearing also resulted in an increase in cortical pyramidal neuron dendritic arborization, but this was inhibited in animals that underwent FPI prior to EE housing [Ip et al., 2002]. Since this injury model does not produce measurable neuronal loss [Gurkoff et al., 2006] and since the animals demonstrate normal open field exploratory behavior [Fineman et al., 2000], the impairment of plasticity seen is presumed to be due to diminished neural function or responsiveness. This period of unresponsiveness to EE has been shown to partially recover by 2 weeks after injury. When P19 pups were subjected to moderate-severe lateral FPI and allowed to recover for 2 weeks prior to differential housing (standard vs. EE), both sham and injured animals showed shorter latencies in the Morris water maze, indicating an augmentation of spatial learning. However, when tested for memory in the probe trial, uninjured $\mathrm{EE}$ animals still outperformed the FPI EE animals, which showed lasting deficits in spatial memory [Giza et al., 2005]. Thus, the 2 -week postinjury

Plasticity after Developmental Traumatic Brain Injury delay allowed for enrichment-induced benefits in task acquisition, but augmentation of memory functions was still impaired.

By examining molecular signals for changes that correlate with diminished 'enrichability', it is interesting to remember that the injury-induced reductions in the NR2A subunit of the NMDA receptor occur within the first postinjury week. Preliminary work looking at whether EE housing rescues the levels of NR2A after injury reveals that these reductions occur independent of housing conditions [Santa Maria et al., 2005].

\section{Chronic Sequelae: Bad Plasticity?}

While the increased neuroplasticity of the developing brain has generally been thought of as beneficial, it is also known that abnormal neural connectivity can result in worsened function and this can be thought of as 'bad plasticity'. One means by which functional deficits may occur is in conjunction with progressive lesions over time, as discussed above. If the injury process evolves over a long time period, then neural connections are being disturbed at the very time when circuit maturation should be occurring. In the model of developmental (P21) mouse CCI, no significant differences in latencies to find the hidden Morris water maze platform were detected when the animals were tested 5 weeks after injury, but in adulthood (over 4 months after injury), the injured animals showed clear acquisition deficits [Pullela et al., 2006]. This delayed impairment is likely due to ongoing injury progression and abnormal reorganization of damaged networks.

A second mechanism by which 'bad plasticity' can manifest negative cognitive consequences is when the initial injury triggers a trophic response but the regrowth of damaged fibers is perturbed. This would occur in the absence of a progressive lesion, so ongoing deafferentation could not be the underlying mechanism. Following an entorhinal cortical lesion in juvenile (P28) rats, the cholinergic axons to the hippocampus regrow in a characteristic manner, and this regrowth is correlated with changes in hippocampal synaptophysin staining. No distinct spatial memory deficits are seen. Animals subjected to fluid percussion injury 1 day prior to entorhinal cortex lesion showed altered patterns of cholinergic fiber regrowth and concomitant impairments of spatial memory [Prins et al., 2003].

A final mechanism of 'bad plasticity' involves selfpropagating neural activation that can result in reinforcement of excitatory circuits, ultimately leading to spontaneous seizures. Chemically induced status epilepticus using lithium pilocarpine clearly has age-dependent patterns 
of acute cell death, mossy fiber sprouting and subsequent epileptogenesis [Sankar et al., 1998]. It is generally accepted that the pediatric population is more vulnerable to both acute posttraumatic seizures and to the development of late posttraumatic epilepsy [Annegers et al., 1998; Annegers and Coan, 2000]. Recently, chronic recordings after P32-35 lateral FPI in rats have shown a high incidence of posttraumatic epilepsy as the animals mature [D'Ambrosio et al., 2004]. Furthermore, the electrical pattern of the neocortical seizures changes with postinjury time and with cerebral maturation, starting as focal seizures, but over time evolving into spreading seizures and eventually into limbic seizures involving hippocampal structures bilaterally [D'Ambrosio et al., 2005]. These studies provide strong evidence for ongoing circuit rearrangement and abnormal plasticity after developmental TBI and result in a clinically relevant and potentially disabling condition.

\section{Summary}

TBI is predominantly a condition of the young brain, and this younger age group has often been credited with enhanced plasticity that results in improved recovery.
However, plasticity is a complex and balanced process that must be precisely executed for optimal maturational outcome. Injuries to the immature brain must be evaluated carefully, and recovery to preinjury baseline is clearly an inadequate endpoint in cases where ongoing development and/or ongoing experience-dependent enrichment are occurring. The pathophysiology of acute TBI results in a multitude of processes that can perturb normal developmental plasticity, including faulty neurotransmission, alterations in molecular signals, necrotic and apoptotic cell death, changes in neural connectivity and function, inhibition of experience-dependent 'good' plasticity and activation of self-propagating 'bad' plasticity. Realizing that the dogma 'younger is better' may be incorrect is the first step to carefully investigating these complex injury effects and devising mechanistic interventions to promote recovery from these often devastating injuries.

\section{Acknowledgements}

Special thanks to Yan Cai and Hong-Hua Li for their contributions to the gene array experiments. Supported by NS02197, NS027544, NS052406, the UCLA Assistant Professor Initiative and the UCLA Brain Injury Research Center.

\section{References}

- Adams CE, Broide RS, Chen Y, Winzer-Serhan UH, Henderson TA, Leslie FM, Freedman R (2002): Development of the alpha7 nicotinic cholinergic receptor in rat hippocampal formation. Brain Res Dev Brain Res 139:175187.

Adelson PD, Dixon CE, Davis DS, Santone D, Gordon A, Jenkins LW, Kochanek PM (2002): Age related effects of acute NMDA blockade on functional outcome after controlled cortical impact in immature rats (abstract). J Neurotrauma 19:1327.

Adelson PD, Jenkins LW, Hamilton RL, Robichaud P, Tran MP, Kochanek PM (2001): Histopathologic response of the immature rat to diffuse traumatic brain injury. J Neurotrauma 18:967-976

Annegers JF, Coan SP (2000): The risks of epilepsy after traumatic brain injury. Seizure 9:453457.

-Annegers JF, Hauser WA, Coan SP, Rocca WA (1998): A population-based study of seizures after traumatic brain injuries. N Engl J Med 338:20-24.
Barlow KM, Thomson E, Johnson D, Minns RA (2005): Late neurologic and cognitive sequelae of inflicted traumatic brain injury in infancy. Pediatrics 116:e174-e185.

Berger-Sweeney J (2003): The cholinergic basal forebrain system during development and its influence on cognitive processes: important questions and potential answers. Neurosci Biobehav Rev 27:401-411.

Biegon A, Fry PA, Paden CM, Alexandrovich A, Tsenter J, Shohami E (2004): Dynamic changes in N-methyl-D-aspartate receptors after closed head injury in mice: implications for treatment of neurological and cognitive deficits. Proc Natl Acad Sci USA 101:5117-5122.

- Bittigau P, Sifringer M, Genz K, Reith E, Pospischil D, Govindarajalu S, Dzietko M, Pesditschek S, Mai I, Dikranian K, Olney JW, Ikonomidou C (2002): Antiepileptic drugs and apoptotic neurodegeneration in the developing brain. Proc Natl Acad Sci USA 99:15089-15094.

Bittigau P, Sifringer M, Pohl D, Stadthaus D, Ishimaru M, Shimizu H, Ikeda M, Lang D, Speer A, Olney JW, Ikonomidou C (1999): Apoptotic neurodegeneration following trauma is markedly enhanced in the immature brain. Ann Neurol 45:724-735.
Blitzer R, Lombroso PJ (2003): Genetics of childhood disorders. 53. Learning and memory, part 6: induction of long-term potentiation. J Am Acad Child Adolesc Psychiatry 42:9981001.

Burgess JW, Villablanca JR (1986): Recovery of function after neonatal or adult hemispherectomy in cats. 2. Limb bias and development, paw usage, locomotion and rehabilitative effects of exercise. Behav Brain Res 20:1-17.

-Card JP, Santone DJ Jr, Gluhovsky MY, Adelson PD (2005): Plastic reorganization of hippocampal and neocortical circuitry in experimental traumatic brain injury in the immature rat. J Neurotrauma 22:989-1002.

Chang EF, Claus CP, Vreman HJ, Wong RJ, NobleHaeusslein LJ (2005): Heme regulation in traumatic brain injury: relevance to the adult and developing brain. J Cereb Blood Flow Metab 25:1401-1417.

Chomczynski P, Sacchi N (1987): Single-step method of RNA isolation by acid guanidinium thiocyanate-phenol-chloroform extraction. Anal Biochem 162:156-159. 
Conti AC, Raghupathi R, Trojanowski JQ, McIntosh TK (1998): Experimental brain injury induces regionally distinct apoptosis during the acute and delayed post-traumatic period. J Neurosci 18:5663-5672.

D'Ambrosio R, Fairbanks JP, Fender JS, Born DE, Doyle DL, Miller JW (2004): Post-traumatic epilepsy following fluid percussion injury in the rat. Brain 127:304-314.

D'Ambrosio R, Fender JS, Fairbanks JP, Simon EA, Born DE, Doyle DL, Miller JW (2005): Progression from frontal-parietal to mesial-temporal epilepsy after fluid percussion injury in the rat. Brain 128:174-188.

D'Ambrosio R, Maris DO, Grady MS, Winn HR, Janigro D (1998): Selective loss of hippocampal long-term potentiation, but not depression, following fluid percussion injury. Brain Res 786:64-79.

D'Ambrosio R, Maris DO, Grady MS, Winn HR, Janigro D (1999): Impaired K(+) homeostasis and altered electrophysiological properties of post-traumatic hippocampal glia. J Neurosc 19:8152-8162.

Dixon CE, Bao J, Long DA, Hayes RL (1996): Reduced evoked release of acetylcholine in the rodent hippocampus following traumatic brain injury. Pharmacol Biochem Behav 53: 679-686.

-Dixon CE, Kochanek PM, Yan HQ, Schiding JK, Griffith RG, Baum E, Marion DW, DeKosky ST (1999): One-year study of spatial memory performance, brain morphology, and cholinergic markers after moderate controlled cortical impact in rats. J Neurotrauma 16:109122.

Dixon CE, Ma X, Marion DW (1997): Reduced evoked release of acetylcholine in the rodent neocortex following traumatic brain injury. Brain Res 749:127-130.

Ewing-Cobbs L, Fletcher JM, Levin HS, Francis DJ, Davidson K, Miner ME (1997): Longitudinal neuropsychological outcome in infants and preschoolers with traumatic brain injury. J Int Neuropsychol Soc 3:581-591.

Ewing-Cobbs L, Fletcher JM, Levin HS, Iovino I, Miner ME (1998): Academic achievement and academic placement following traumatic brain injury in children and adolescents: a two-year longitudinal study. J Clin Exp Neuropsychol 20:769-781.

Faden AI, Demediuk P, Panter SS, Vink R (1989): The role of excitatory amino acids and NMDA receptors in traumatic brain injury. Science 244:798-800.

Fan P, Yamauchi T, Noble LJ, Ferriero DM (2003): Age-dependent differences in glutathione peroxidase activity after traumatic brain injury. J Neurotrauma 20:437-445.

Fay GC, Jaffe KM, Polissar NL, Liao S, Rivara JB, Martin KM (1994): Outcome of pediatric traumatic brain injury at three years: a cohort study. Arch Phys Med Rehabil 75:733-741.
Felt BT, Schallert T, Shao J, Liu Y, Li X, Barks JD (2002): Early appearance of functional deficits after neonatal excitotoxic and hypoxic-ischemic injury: fragile recovery after development and role of the NMDA receptor. Dev Neurosci 24:418-425.

Fineman I, Giza CC, Nahed BV, Lee SM, Hovda DA (2000): Inhibition of neocortical plasticity during development by a moderate concussive brain injury. J Neurotrauma 17:739-749.

Flint AC, Maisch US, Weishaupt JH, Kriegstein AR, Monyer H (1997): NR2A subunit expression shortens NMDA receptor synaptic currents in developing neocortex. J Neurosci 17: 2469-2476.

Fox GB, Fan L, LeVasseur RA, Faden AI (1998): Sustained sensory/motor and cognitive deficits with neuronal apoptosis following controlled cortical impact brain injury in the mouse. J Neurotrauma 15:599-614.

Giza CC, Griesbach GS, Hovda DA (2005): Experience-dependent behavioral plasticity is disturbed following traumatic injury to the immature brain. Behav Brain Res 157:11-22.

- Giza CC, Prins ML, Hovda DA, Herschman HR, Feldman JD (2002): Genes preferentially induced by depolarization after concussive brain injury: effects of age and injury severity. J Neurotrauma 19:387-402.

Giza CC, Santa Maria NS, Hovda DA (in press): $\mathrm{N}$-methyl-D-aspartate receptor subunit changes following traumatic injury to the developing brain. J Neurotrauma.

Golarai G, Greenwood AC, Feeney DM, Connor JA (2001): Physiological and structural evidence for hippocampal involvement in persistent seizure susceptibility after traumatic brain injury. J Neurosci 21:8523-8537.

Goldman PS (1971): Functional development of the prefrontal cortex in early life and the problem of neuronal plasticity. Exp Neurol 32: 366-387.

Gorman LK, Fu K, Hovda DA, Murray M, Traystman RJ (1996): Effects of traumatic brain injury on the cholinergic system in the rat. J Neurotrauma 13:457-463.

Greenough WT, Volkmar FR, Juraska JM (1973): Effects of rearing complexity on dendritic branching in frontolateral and temporal cortex of the rat. Exp Neurol 41:371-378.

Griesbach GS, Hovda DA, Molteni R, Gomez-Pinilla F (2002): Alterations in BDNF and synapsin I within the occipital cortex and hippocampus after mild traumatic brain injury in the developing rat: reflections of injury-induced neuroplasticity. J Neurotrauma 19;803814.

Griesbach GS, Hovda DA, Molteni R, Wu A, Gomez-Pinilla F (2004): Voluntary exercise following traumatic brain injury: brain-derived neurotrophic factor upregulation and recovery of function. Neuroscience 125:129-139.

Griffin SL, van Reekum R, Masanic C (2003): A review of cholinergic agents in the treatment of neurobehavioral deficits following traumatic brain injury. J Neuropsychiatry Clin Neurosci 15:17-26.
Gurkoff G, Giza CC, Hovda DA (2006): Lateral fluid percussion injury in the developing rat causes an acute, mild behavioral dysfunction in the absence of significant cell death. Brain Res 1077:24-36.

-Hensch TK, Fagiolini M, Mataga N, Stryker MP, Baekkeskov S, Kash SF (1998): Local GABA circuit control of experience-dependent plasticity in developing visual cortex. Science 282: 1504-1508.

Ikonomidou C, Mosinger JL, Salles KS, Labruyere J, Olney JW (1989): Sensitivity of the developing rat brain to hypobaric/ischemic damage parallels sensitivity to $\mathrm{N}$-methyl-aspartate neurotoxicity. J Neurosci 9:2809-2818.

Ikonomidou C, Qin Y, Labruyere J, Kirby C, Olney JW (1996): Prevention of trauma-induced neurodegeneration in infant rat brain. Pediatr Res 39:1020-1027.

Ip EY, Giza CC, Griesbach GS, Hovda DA (2002): Effects of enriched environment and fluid percussion injury on dendritic arborization within the cerebral cortex of the developing rat. J Neurotrauma 19:573-585.

Jacobs B, Schall M, Scheibel AB (1993): A quantitative dendritic analysis of Wernicke's area in humans. 2. Gender, hemispheric, and environmental factors. J Comp Neurol 327:97111.

Jaffe KM, Fay GC, Polissar NL, Martin KM, Shurtleff HA, Rivara JM, Winn HR (1993): Severity of pediatric traumatic brain injury and neurobehavioral recovery at one year - a cohort study. Arch Phys Med Rehabil 74:587595.

Jenkins LW, Peters GW, Dixon CE, Zhang X, Clark RS, Skinner JC, Marion DW, Adelson PD, Kochanek PM (2002): Conventional and functional proteomics using large format two-dimensional gel electrophoresis 24 hours after controlled cortical impact in postnatal day 17 rats. J Neurotrauma 19:715-740.

Jevtovic-Todorovic V, Hartman RE, Izumi Y, Benshoff ND, Dikranian K, Zorumski CF, Olney JW, Wozniak DF (2003): Early exposure to common anesthetic agents causes widespread neurodegeneration in the developing rat brain and persistent learning deficits. J Neurosci 3: 876-882.

Johnston MV (2004): Clinical disorders of brain plasticity. Brain Dev 26:73-80.

Katayama Y, Becker DP, Tamura T, Hovda DA (1990): Massive increases in extracellular potassium and the indiscriminate release of glutamate following concussive brain injury. J Neurosurg 73:889-900.

Kawamata T, Hovda DA, Yoshino A (1992): Administration of excitatory amino acid antagonists via microdialysis prevents the increase in glucose utilization seen immediately following concussive brain injury (abstract). Soc Neurosci 16:778.

Kennard MA (1942): Cortical reorganization of motor function: studies on a series of monkeys of various ages from infancy to maturity. Arch Neurol Psychiatry 48:227-240. 
Kolb B, Cioe J (2000): Recovery from early cortical damage in rats. 8. Earlier may be worse: behavioural dysfunction and abnormal cerebral morphogenesis following perinatal frontal cortical lesions in the rat. Neuropharmacology 39:756-764.

Kolb B, Cioe J, Whishaw IQ (2000): Is there an optimal age for recovery from motor cortex lesions? 1. Behavioral and anatomical sequelae of bilateral motor cortex lesions in rats on postnatal days 1,10 , and in adulthood. Brain Res 882:62-74.

Kolb B, Petrie B, Cioe J (1996): Recovery from early cortical damage in rats. 7. Comparison of the behavioural and anatomical effects of medial prefrontal lesions at different ages of neural maturation. Behav Brain Res 79:1-14.

Kolb B, Tomie J (1988): Recovery from early cortical damage in rats. 4 . Effects of hemidecortication at 1,5 or 10 days of age on cerebral anatomy and behavior. Behav Brain Res 28: 259-274.

Konrad K, Gauggel S, Schurek J (2003): Catecholamine functioning in children with traumatic brain injuries and children with attention-deficit/hyperactivity disorder. Brain Res Cogn Brain Res 16;425-433.

- Kumar A, Cook IA (2002): White matter injury, neural connectivity and the pathophysiology of psychiatric disorders. Dev Neurosci 24: 255-261.

Kumar A, Zou L, Yuan X, Long Y, Yang K (2002): $\mathrm{N}$-methyl-D-aspartate receptors: transient loss of NR1/NR2A/NR2B subunits after traumatic brain injury in a rodent model. J Neurosci Res 67:781-786.

-Leggio MG, Mandolesi L, Federico F, Spirito F, Ricci B, Gelfo F, Petrosini L (2005): Environmental enrichment promotes improved spatial abilities and enhanced dendritic growth in the rat. Behav Brain Res 163:78-90.

Levin HS (2003): Neuroplasticity following nonpenetrating traumatic brain injury. Brain Inj 17:665-674.

Levin HS, Aldrich EF, Saydjari C, Eisenberg HM, Foulkes MA, Bellefleur M, Luerssen TG, Jane JA, Marmarou A, Marshall LF (1992): Severe head injury in children: experience of the Traumatic Coma Data Bank. Neurosurgery 31:435-443.

- Levin HS, Eisenberg HM, Wigg NR, Kobayashi K (1982): Memory and intellectual ability after head injury in children and adolescents. Neurosurgery 11:668-673.

Levin HS, Hanten G, Chang CC, Zhang L, Schachar R, Ewing-Cobbs L, Max JE (2002): Working memory after traumatic brain injury in children. Ann Neurol 52:82-88.

- Liu D, Diorio J, Day JC, Francis DD, Meaney MJ (2000): Maternal care, hippocampal synaptogenesis and cognitive development in rats. Nat Neurosci 3:799-806.

Liu L, Wong TP, Pozza MF, Lingenhoehl K, Wang Y, Sheng M, Auberson YP, Wang YT (2004): Role of NMDA receptor subtypes in governing the direction of hippocampal synaptic plasticity. Science 304:1021-1024.
Lowenstein DH, Thomas MJ, Smith DH, McIntosh TK (1992): Selective vulnerability of dentate hilar neurons following traumatic brain injury: a potential mechanistic link between head trauma and disorders of the hippocampus. J Neurosci 12:4846-4853.

Miller EA, Goldman PS, Rosvold HE (1973): Delayed recovery of function following orbital prefrontal lesions in infant monkeys. Science 182:304-306.

Miller LP, Lyeth BG, Jenkins LW, Oleniak L, Panchision D, Hamm RJ, Phillips LL, Dixon CE, Clifton GL, Hayes RL (1990): Excitatory amino acid receptor subtype binding following traumatic brain injury. Brain Res 526:103107.

-Miyoshi R, Kito S, Shimizu M, Matsubayashi H (1987): Ontogeny of muscarinic receptors in the rat brain with emphasis on the differentiation of M1- and M2-subtypes - semi-quantitative in vitro autoradiography. Brain Res 420: 302-312.

Natale JE, Knight JB, Cheng Y, Rome JE, Gallo V (2004): Metallothionein I and II mitigate agedependent secondary brain injury. J Neurosci Res 78:303-314.

Noble KG, Norman MF, Farah MJ (2005): Neurocognitive correlates of socioeconomic status in kindergarten children. Dev Sci 8:74-87.

Osteen CL, Giza CC, Hovda DA (2004): Injuryinduced alterations in N-methyl-D-aspartate receptor subunit composition contribute to prolonged (45)calcium accumulation following lateral fluid percussion. Neuroscience 128 : 305-322.

>Phillips LL, Lyeth BG, Hamm RJ, Povlishock JT (1994): Combined fluid percussion brain injury and entorhinal cortical lesion: a model for assessing the interaction between neuroexcitation and deafferentation. J Neurotrauma 11:641-656.

Pohl D, Bittigau P, Ishimaru MJ, Stadthaus D, Hubner C, Olney JW, Turski L, Ikonomidou C (1999): N-methyl-D-aspartate antagonists and apoptotic cell death triggered by head trauma in developing rat brain. Proc Natl Acad Sci USA 96:2508-2513.

Prins ML, Giza CC (2006): Induction of monocarboxylate transporter 2 expression and ketone transport following traumatic brain injury in juvenile adult rats. Dev Neurosci 28:447-456.

Prins ML, Hovda DA (2003): Developing experimental models to address traumatic brain injury in children. J Neurotrauma 20:123137.

Prins ML, Lee SM, Cheng CL, Becker DP, Hovda DA (1996): Fluid percussion brain injury in the developing and adult rat: a comparative study of mortality, morphology, intracranial pressure and mean arterial blood pressure. Brain Res Dev Brain Res 95:272-282.

Prins ML, Povlishock JT, Phillips LL (2003): The effects of combined fluid percussion traumatic brain injury and unilateral entorhinal deafferentation on the juvenile rat brain. Brain Res Dev Brain Res 140:93-104.
Pullela R, Raber J, Pfankuch T, Ferriero DM, Claus CP, Koh SE, Yamauchi T, Rola R, Fike JR, Noble-Haeusslein LJ (2006): Traumatic injury to the immature brain results in progressive neuronal loss, hyperactivity and delayed cognitive impairments. Dev Neurosci 28:396-409.

Quinlan EM, Olstein DH, Bear MF (1999a): Bidirectional, experience-dependent regulation of $\mathrm{N}$-methyl-D-aspartate receptor subunit composition in the rat visual cortex during postnatal development. Proc Natl Acad Sci USA 96:12876-12880.

Quinlan EM, Philpot BD, Huganir RL, Bear MF (1999b): Rapid, experience-dependent expression of synaptic NMDA receptors in visual cortex in vivo. Nat Neurosci 2:352-357.

Ricceri L (2003): Behavioral patterns under cholinergic control during development: lessons learned from the selective immunotoxin 192 IgG saporin. Neurosci Biobehav Rev 27:377384 .

Roberts EB, Ramoa AS (1999): Enhanced NR2A subunit expression and decreased NMDA receptor decay time at the onset of ocular dominance plasticity in the ferret. J Neurophysiol 81:2587-2591.

Rosenzweig MR, Bennett EL (1996): Psychobiology of plasticity: effects of training and experience on brain and behavior. Behav Brain Res 78:57-65.

Sanders MJ, Sick TJ, Perez-Pinzon MA, Dietrich WD, Green EJ (2000): Chronic failure in the maintenance of long-term potentiation following fluid percussion injury in the rat. Brain Res 861:69-76.

Sankar R, Shin DH, Liu H, Mazarati A, Pereirad V, Wasterlain CG (1998): Patterns of status epilepticus-induced neuronal injury during development and long-term consequences. J Neurosci 18:8382-8393.

Santa Maria NS, Hovda DA, Giza CC (2005): Traumatic brain injury, enriched environment and N-methyl-D-aspartate receptormediated neuroplasticity in the immature rat (abstract). Ann Neurol 58(suppl 9):S82.

-Shao L, Ciallella JR, Yan HQ, Ma X, Wolfson BM, Marion DW, DeKosky ST, Dixon CE (1999): Differential effects of traumatic brain injury on vesicular acetylcholine transporter and M2 muscarinic receptor $\mathrm{mRNA}$ and protein in rat. J Neurotrauma 16:555-566.

Sick TJ, Perez-Pinzon MA, Feng ZZ (1998): Impaired expression of long-term potentiation in hippocampal slices 4 and $48 \mathrm{~h}$ following mild fluid-percussion brain injury in vivo. Brain Res 785:287-292.

Sihver S, Marklund N, Hillered L, Langstrom B, Watanabe Y, Bergstrom M (2001): Changes in $\mathrm{mACh}, \mathrm{NMDA}$ and $\mathrm{GABA}(\mathrm{A})$ receptor binding after lateral fluid-percussion injury: in vitro autoradiography of rat brain frozen sections. J Neurochem 78:417-423. 
Takahashi T, Feldmeyer D, Suzuki N, Onodera K, Cull-Candy SG, Sakimura K, Mishina M (1996): Functional correlation of NMDA receptor epsilon subunits expression with the properties of single-channel and synaptic currents in the developing cerebellum. J Neurosci 16:4376-4382.

Tang YP, Wang $\mathrm{H}$, Feng R, Kyin M, Tsien JZ (2001): Differential effects of enrichment on learning and memory function in NR2B transgenic mice. Neuropharmacology 41: 779-790.
Taylor HG, Alden J (1997): Age-related differences in outcomes following childhood brain in sults: an introduction and overview. J Int Neuropsychol Soc 3:555-567.

Tong W, Igarashi T, Ferriero DM, Noble LJ (2002): Traumatic brain injury in the immature mouse brain: characterization of regional vulnerability. Exp Neurol 176:105-116.

Toth Z, Hollrigel GS, Gorcs T, Soltesz I (1997): Instantaneous perturbation of dentate interneuronal networks by a pressure wave-transient delivered to the neocortex. J Neurosci 17: 8106-8117.

- Tovar KR, Westbrook GL (1999): The incorporation of NMDA receptors with a distinct subunit composition at nascent hippocampal synapses in vitro. J Neurosci 19:4180-4188.
Venable N, Pinto-Hamuy T, Arraztoa JA, Contador MT, Chellew A, Peran C, Valenzuela X (1988): Greater efficacy of preweaning than postweaning environmental enrichment on maze learning in adult rats. Behav Brain Res 31:89-92.

Walter B, Brust P, Fuchtner F, Muller M, Hinz R, Kuwabara H, Fritz H, Zwiener U, Bauer R (2004): Age-dependent effects of severe traumatic brain injury on cerebral dopaminergic activity in newborn and juvenile pigs. J Neurotrauma 21:1076-1089. 